\title{
Spatial and temporal patterns of distribution and abundance of chaetodontid fishes at One Tree Reef, southern GBR
}

\author{
Anthony J. Fowler* \\ School of Biological Sciences, University of Sydney, NSW 2006, Australia
}

\begin{abstract}
Between November 1984 and April 1987, the butterflyfishes of One Tree Reef on the southern Great Barrier Reef were sampled on 8 occasions at 9 widely dispersed localities across the reef using a hierarchial sampling regime. Data were collected on 23 species which fell into 3 categories of abundance. Three 'abundant' species each contributed $>10 \%$ of the total of all individuals. Five species were 'common', each contributing 2 to $10 \%$ of the total, and 15 species were 'rare', each contributing $<1.0 \%$ of the tolal. The 8 'abundant' and 'common' species were present at all localities, whilst 11 of the 'rare' species had restricted and discontinuous distributions. The former 8 demonstrated significant differences in abundance amongst localities, 5 of which also had significant differences amongst sites (within combinations of occasions and localities). Relationships between fish abundance and coral abundance were weak, and could not predict these spatial patterns. The size structures of the 3 abundant species indicated consistent spatial differences, implying different population dynamics occurring on adjacent and local areas of reef. Five abundant and common species showed significant temporal variation, 2 species showed a seasonal pattern of variation, and 3 species showed increases in population density. Generally, however, spatial differences amongst localities were maintained through time.
\end{abstract}

\section{INTRODUCTION}

A fundamental aim of ecological studies is to explain the spatial and temporal variation in the sizes and distributions of populations, and the structures of communities. For coral reef fish, population densities can be the greatest of any vertebrate taxon in any ecosystem, and their communities are legendary for their high diversity (Connell 1978). Despite considerable research effort, particularly in the past $10 \mathrm{yr}$, the processes that determine such characteristics are still contentious and a source of debate (Sale 1980, Doherty \& Williams 1988).

Mapstone \& Fowler (1988) concluded that more data on population dynamics and demography would be required to develop plausible hypotheses regarding population regulation and community characteristics of coral reef fish. A significant step in this process is to obtain accurate and precise estimates of distribution and abundance at relevant scales of space and time

- Present address: Australian Institute of Marine Science, PMB No. 3, Townsville, M.C., Queensland 4810, Australia
(Jones 1988). The work described in this paper explores spatial and temporal variation in the distribution and abundance of populations of chaetodonts (butterflyfishes), and the characteristics of the local assemblages they comprise, on one reef on the Great Barrier Reef (GBR). Particular emphasis has been placed on comparisons amongst populations occupying different areas of the reef, that present different habitat types, to assess spatial variability in the various population characteristics.

Chaetodontid fishes are important members of the ichthyofauna associated with coral reefs around the world (Allen 1981, Williams \& Hatcher 1983). Because the diets of many chaetodonts rely on corals (HarmelinVivien \& Bouchon-Navaro 1983) and their abundances have been related to this food source (Bell \& Galzin 1984, Bouchon-Navaro 1986, Bouchon-Navaro \& Bouchon 1989), it has been suggested that these fish are important indicator species for assessing the healthiness of coral reefs (Reese 1981, Hourigan et al. 1988). Yet, this consideration may be preliminary as it assumes that populations of chaetodonts are resourcedetermined. To date, conclusions about the limitation 
of populations of chaetodonts have been inferred from static pictures of distribution and abundance (Clarke 1977. Anderson et al. 1981, Bell et al. 1985, Findley \& Findley 1985, Bouchon-Navaro 1986) and their relationship with coral abundance (Bell \& Galzin 1984, Bouchon-Navaro 1986). Yet such methodologies lack rigour in identifying processes (Connell 1978, Colwell 1983, Sale 1984, Wiens 1984, Sale et al. 1985, Mapstone \& Fowler 1988). Furthermore, the work done to date on chaetodonts has other limitations. No consideration has yet been made of the temporal variation in the sizes of populations of chaetodonts, and most sampling programmes have considered only adult fish. Furthermore, some relationships between fish and coral abundance have been at best only weak (Bell et al. 1985, Findley \& Findley 1985). Given this, any conclusions regarding the regulation of the sizes of populations of chaetodonts can at best be described as preliminary.

The intention here was to provide a more thorough description of the demographic features of the populations of several species of chaetodonts from the Great Barrier Reef of Australia, on which hypotheses about the regulation of populations could be based. The specific aims addressed were to: (1) describe the spatial and temporal variation in the abundance, distribution and the size structure of individual species of chaetodonts; (2) describe the spatial and temporal variation in the structure of assemblages of chaetodonts; (3) describe the relationships between abundance of chaetodonts and live coral cover.

\section{MATERIALS AND METHODS}

Sampling procedures. The study was done at One Tree Reef $\left(23^{\circ} 30^{\prime} \mathrm{S}, 152^{\circ} 06^{\prime} \mathrm{E}\right)$ on the eastern edge of the Capricorn Group of reefs on the southern Great Barrier Reef of Australia between 1984 and 1987. Chaetodontid populations were sampled on 8 occasions spanning 30 mo in 9 different localities, defined as discrete areas of reef supporting relatively uniform habitat. These localities occurred in 3 reef zones and differed in orientation from horizontal to vertical, in aspect to prevailing winds and currents, and in distance from the reef crest (Fig. 1, Table 1). The characteristics of the substratum at each locality were documented once and this was compared to the fish populations present at that time.

Analysis of substrata. In January 1985, the substratum within each of the 9 localities was quantified along 3 transects within each of 2 sites. Along each transect of $75 \mathrm{~m}$ length, 2 quadrats were sampled at each of 6 positions (15 $\mathrm{m}$ intervals). The quadrat, consisting of a 25 point regular grid within an area of $50 \times 50 \mathrm{~cm}$, was placed next to the transect line and the substratum under each grid point was recorded. Five categories of coral were distinguished: Porites spp., Acropora spp., Pocillopora damicornis, other hard corals, and soft corals (sub-class Alcyonaria, order Alcyonacea). One estimate for each category was obtained for each transect by pooling the data from the 12 quadrats and converting this to a percentage of the total area sampled. Each category was analysed for differences amongst localities and sites (within localities) by a nested analysis of variance.

Analysis of fish populations. On 8 occasions (November 1984, January, April, August, November 1985, March and November 1986, and April 1987), each of the 9 localities was sampled at 2 haphazardly chosen sites. Chaetodonts were counted along 3 random transects of $75 \times 2 \mathrm{~m}$ at each site, using an underwater visual sampling technique specially adapted for

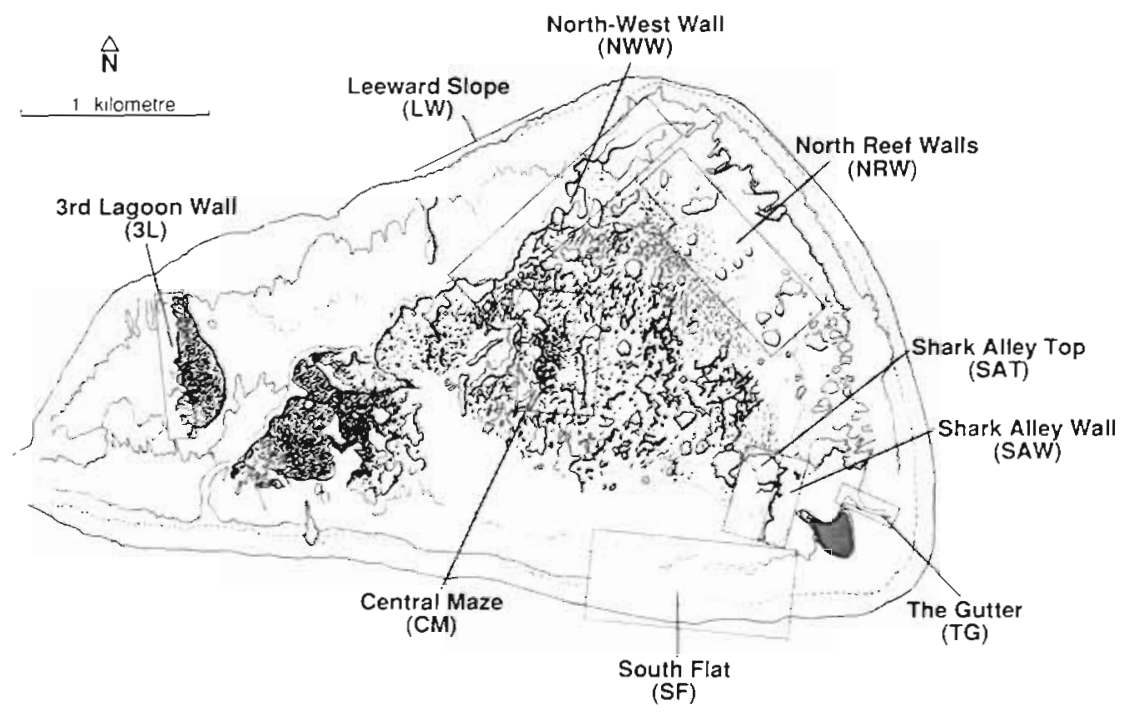

Fig. 1. Location on One Tree Reef of the 9 localities considered in the sampling program 
Table 1. Summary of characteristics of localities considered in the sampling program, and indicated on Fig. 1. LWD: low water depth

\begin{tabular}{|c|c|c|c|}
\hline Locality & Abbreviation & Reef Zone & Habitat \\
\hline Gutter & $\mathrm{TG}$ & Lagoon & $\begin{array}{l}\text { Horizontal sandy area, numerous coral bommies, low sprawl- } \\
\text { ing coral gardens. Important gutter for tidal flow. LWD }=2 \mathrm{~m}\end{array}$ \\
\hline Shark Alley Wall & SAW & Lagoon & Vertical wall, moderate tidal currents. LWD $=3 \mathrm{~m}$ \\
\hline Shark Alley Top & SAT & Lagoon & $\begin{array}{l}\text { Horizontal sandy area, numerous small bommies and coral } \\
\text { heads. Moderate/strong tidal flow. LWD }=1.5 \mathrm{~m}\end{array}$ \\
\hline South Flat & $\mathrm{SF}$ & Reef flat & $\begin{array}{l}\text { Reef patches punctuated by sandy surge channels perpen- } \\
\text { dicular to reef rim. Strong flood tide currents. } L W D=1 \mathrm{~m}\end{array}$ \\
\hline Central Maze & $\mathrm{CM}$ & Lagoon & $\begin{array}{l}\text { Vertical wall of elongate, reticulated reef maze, tidal currents } \\
\text { weak. LWD }=3 \mathrm{~m}\end{array}$ \\
\hline North Reef Walls & NRW & Lagoon & $\begin{array}{l}\text { Vertical walls of large micro-atolls (>100 m diameter), tidal } \\
\text { currents generally weak. LWD }=3 \mathrm{~m}\end{array}$ \\
\hline North-West Wall & NWW & Lagoon & $\begin{array}{l}\text { Continuous vertical wall inside reef rim, tidal currents gener- } \\
\text { ally weak, but moderate on ebbing tide. } \mathrm{LWD}=4 \mathrm{~m}\end{array}$ \\
\hline 3rd Lagoon Wall & $3 \mathrm{~L}$ & Lagoon & $\begin{array}{l}\text { Continuous vertical wall inside reef rim, tidal currents gener- } \\
\text { ally weak. LWD }=4 \mathrm{~m}\end{array}$ \\
\hline Leeward Slope & LW & Reef slope & $\begin{array}{l}\text { Slope with spur and groove formation and high cover of } \\
\text { tabulate Acropora spp. Currents moderate to strong. Depth } \\
\text { range considered } 5-15 \mathrm{~m}\end{array}$ \\
\hline
\end{tabular}

these fishes (Fowler 1987). A reel with $75 \mathrm{~m}$ of cord was used to measure transect length. The end of this cord was fixed to the substratum and as it was unrolled whilst swimming slowly (ca $10 \mathrm{~m} \mathrm{~min}^{-1}$ ), all adult and sub-adult fish within a $2 \mathrm{~m}$ wide path were counted. The same transect was then sampled for the more cryptic juveniles by searching over a width of $1 \mathrm{~m}$, whilst swimming down one side of the cord and then back along the other. All species of chaetodonts were counted except 4 species of the genus Heniochus, which are difficult to see and identify as they hide in crevices and holes (Anderson et al. 1981).

Data considered in analyses were: total number of species; total number of individuals across all species; and total number of individuals for the more abundant taxa. In each case, the data were tested for differences amongst localities, between sites within localities, and for changes over time by analysis of variance using the specific model $X_{i j k l}=\mu+O_{i}+L_{j}+S_{k(i j)}+O_{i j}+e_{l(i j k)}$ $[\mathrm{O}, \mathrm{L}$ and $\mathrm{S}$ refer to the factors: occasions, localities and sites; other symbols as per Sokal \& Rohlf (1981)]. The model for this analysis, with mean square estimates and F-ratios, as determined by treating occasions and localities as fixed factors and sites as a random factor, is presented in Table 2. Prior to all analyses, data were tested for homogeneity of variances using Cochran's test and when found to be heterogeneous, were transformed using square root $(x+1)$, which in most cases satisfactorily made variances homogeneous. Where an ANOVA detected significant differences, logical groupings of means were compared using StudentNewman-Keuls (SNK) tests.

For each locality, the diversity of the chaetodontid fauna was calculated using the Shannon-Wiener index $\left(\mathrm{H}^{\prime}=-\Sigma \mathrm{p}_{\mathrm{i}} \log _{\mathrm{e}} \mathrm{p}_{\mathrm{i}}\right)$ (Pielou 1974), based on the total counts for each species over the 8 sampling occasions. Here $p_{i}$ is the proportion of the total counts per locality accounted for by species $i$. The habitat width $\left(\mathrm{AH}^{\prime}\right)$ was calculated for each species again based on the Shannon-Wiener index using the total number of counts

Table 2. Estimates of mean squares and F-ratios used in the general model of analysis of variance most often used in this study. $O$ $\mathrm{L}$ and $\mathrm{S}$ refer to the factors: occasions, localities and sites; other symbols as per Sokal \& Rohlf (1981)

\begin{tabular}{|c|c|c|c|}
\hline Term & $\mathrm{df}$ & MS estimate & F-ratio \\
\hline $\begin{array}{l}\text { Occasions } \\
\text { Localities } \\
\text { Sites }\end{array}$ & $\begin{array}{r}7 \\
8 \\
72\end{array}$ & $\begin{array}{l}M S_{O}=\sigma_{e}^{2}+n \sigma^{2}+b c n \sigma_{s}^{2} \\
M S_{L}=\sigma_{e}^{2}+n \sigma^{2}+a c n \sigma_{L}^{2} \\
M S_{S}=\sigma_{e}^{2}+n \sigma_{s}^{2}\end{array}$ & $\begin{array}{l}\mathrm{MS}_{\mathrm{O}} / \mathrm{MS}_{\mathrm{S}} \\
\mathrm{MS}_{\mathrm{L}} / \mathrm{MS}_{\mathrm{S}} \\
\mathrm{MS}_{\mathrm{S}} / \mathrm{MS}_{\mathrm{e}}\end{array}$ \\
\hline $\begin{array}{l}\text { Occasions } \times \text { Localities } \\
\text { Residual } \\
\text { Total }\end{array}$ & $\begin{array}{r}56 \\
288 \\
431\end{array}$ & $\begin{array}{l}\mathrm{MS}_{\mathrm{OL}}=\sigma^{2}{ }_{\mathrm{e}}+n \sigma^{2}{ }_{s}+\mathrm{cn} \sigma^{2} \mathrm{Ol} \\
\mathrm{MS}_{\mathrm{e}}=\sigma_{\mathrm{e}}^{2}\end{array}$ & $\mathrm{MS}_{\mathrm{OL}} / \mathrm{MS}_{\mathrm{S}}$ \\
\hline
\end{tabular}


for each species at each locality. Here, $\mathrm{AH}^{\prime}=$ $-2.7183 \Sigma p_{\mathrm{l}} \log _{e} \mathrm{p}_{i}$ (Pielou 1974), where $\mathrm{p}_{\mathrm{i}}$ is the proportion of the total count for each species recorded in locality i.

Each individual of Chaetodon rainfordi, C. plebius and Chelmon rostratus was classified into one of 6 size classes: $0-20,21-40,41-60,61-80,81-100$ and $>100 \mathrm{~mm}$ standard length (SL). As these sizes were estimated, the procedure was standardised by estimating the sizes of tagged fish of known size. Because the resulting size-class data are not independent amongst size classes, the whole data-set could not be considered by analysis of variance. Alternatively, for each species a subset of the data, i.e. one size class, was analysed using the statistical model from above (Table 2), to indicate whether the relative proportion of the total comprised by this size class varied in space and time.

\section{RESULTS}

\section{Analysis of substrata}

Coral cover and composition differed significantly amongst localities (Fig. 2). Highest covers (> 70\% live coral) were at Leeward Slope, 3rd Lagoon and Central Maze, whilst the lowest was at North Reef Walls with $17 \%$ (Fig. 2a). Porites spp. were significantly more abundant at the North-West Wall than at Central Maze and Leeward Slope (Fig. 2b), whilst alternatively Acropora spp. were significantly more abundant at the latter 2 localities than elsewhere (Fig. 2c). Tabulate Acropora spp. were dominant on the reef slope and large thickets of branching Acropora spp. predominated in the protected Central Maze, in the centre of the lagoon. Pocillopora damicornis was relatively uncommon and did not vary significantly amongst localities (Fig. 2d).

\section{Analysis of fish populations}

In total, 23 of the 32 species of chaetodonts recorded from the Capricorn section of the Great Barrier Reef of Australia (Russell 1983), were recorded at some time in the 432 transects over the 30 mo (Table 3 ). The number of species recorded in the different localities ranged from 10 at North Reef Walls to 20 on the Leeward Slope (Table 3). The mean number of species per $150 \mathrm{~m}^{2}$ varied significantly amongst localities, as more were observed in several of the western localities, including both lagoon and reef slope, than the eastern localities (Table 4 a). The mean number of species observed also varied amongst sampling occasions with a trend towards higher means in autumn (Table 4a).
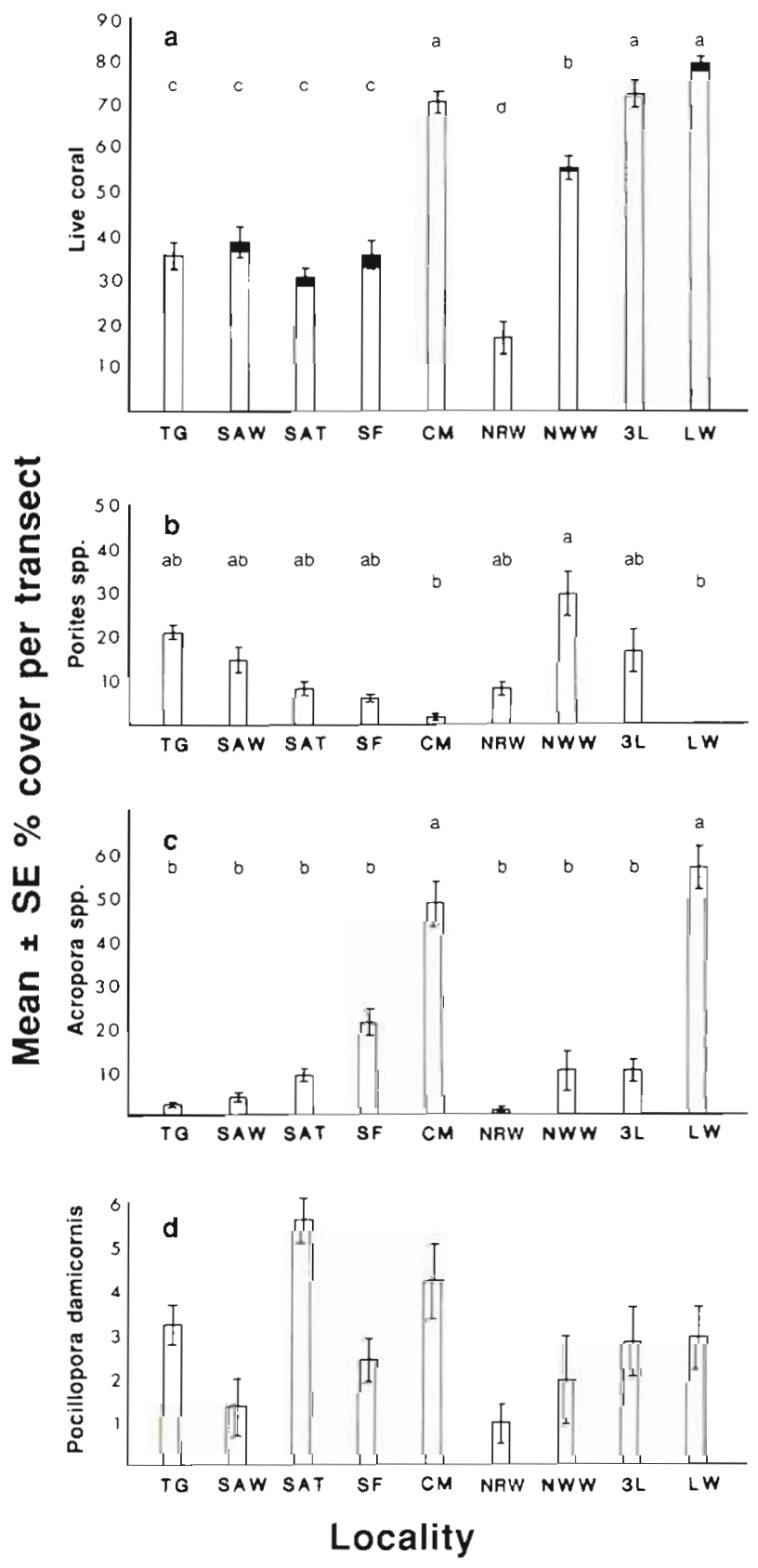

soft coral

Fig. 2. (a) Total live coral; (b) Porites spp.; (c) Acropora spp.; (d) Pocillopora damicornis. Relative abundances in the 9 localities as measured in January 1985. Note the different Yaxis scale for $P$. damicornis. Results of SNK tests are indicated by letters above histograms (means with the same letter are not significantly different)

A total of 9357 fish were counted over the $30 \mathrm{mo}$ period, ranging from a total of 595 fish at North Reef Walls to 1780 on the Leeward Slope. This latter locality always supported the highest density of chaetodonts 
Table 3. Chaetodon (C.) spp., Chelmon (Ch.) rostratus and Forcipiger flavissimus. Total counts of 23 species of chaetodonts at 9 localities at One Tree Reef over 8 sampling occasions. Also shown are total for each species across all localities, total for each locality across all species, appropriate percentages and habitat width for each species and diversity for each locality. Locality abbreviations correspond to those given on Fig. 1. Abundance categories; A: abundant; C: common; R: rare

\begin{tabular}{|c|c|c|c|c|c|c|c|c|c|c|c|c|c|}
\hline Species & $\begin{array}{l}\text { Abun- } \\
\text { dance } \\
\text { category }\end{array}$ & TG & SAW & SAT & $\mathrm{SF}$ & $\mathrm{CM}$ & NRW & NWW & $3 \mathrm{~L}$ & LW & Total & $\begin{array}{l}\% \text { of } \\
\text { total }\end{array}$ & $\begin{array}{c}\text { Habitat } \\
\text { width } \\
\left(\mathrm{AH}^{\prime}\right)\end{array}$ \\
\hline C. rainfordi & $\mathrm{A}$ & 352 & 406 & 604 & 339 & 229 & 176 & 352 & 361 & 1207 & 4026 & 43.0 & 5.51 \\
\hline C. plebius & $A$ & 171 & 121 & 143 & 67 & 156 & 49 & 126 & 143 & 107 & 1083 & 11.6 & 5.82 \\
\hline Ch. rostratus & $\mathrm{A}$ & 99 & 203 & 78 & 38 & 181 & 210 & 136 & 57 & 17 & 1019 & 10.9 & 5.43 \\
\hline C. flavirostris & $\mathrm{C}$ & 87 & 77 & 24 & 133 & 91 & 88 & 148 & 76 & 49 & 773 & 8.3 & 5.72 \\
\hline C. trifasciatus & $\mathrm{C}$ & 20 & 61 & 14 & 9 & 78 & 4 & 109 & 232 & 147 & 674 & 7.2 & 4.71 \\
\hline C. melannotus & C & 36 & 83 & 47 & 61 & 208 & 24 & 142 & 27 & 39 & 667 & 7.1 & 5.25 \\
\hline C. auriga & $\mathrm{C}$ & 82 & 38 & 53 & 32 & 57 & 29 & 71 & 7 & 2 & 371 & 4.0 & 5.34 \\
\hline C. Lineolatus & C & 31 & 17 & 10 & 54 & 52 & 11 & 54 & 30 & 4 & 263 & 2.8 & 5.35 \\
\hline C. trifascialis & $\mathrm{R}$ & - & 2 & - & 4 & 25 & - & - & - & 52 & 83 & 0.9 & 2.42 \\
\hline C. aureofasciatus & $\mathrm{R}$ & 2 & 9 & 5 & - & 2 & - & 3 & 19 & 21 & 61 & 0.7 & 4.32 \\
\hline C. ulietensis & $\mathrm{R}$ & - & 8 & - & - & 1 & -- & 4 & 43 & 2 & 58 & 0.6 & 2.35 \\
\hline C. speculum & $\mathrm{R}$ & 5 & 5 & 2 & 10 & 12 & - & 4 & 3 & 4 & 45 & 0.5 & 5.23 \\
\hline C. ephippium & $\mathrm{R}$ & - & 2 & 2 & 1 & 7 & - & 7 & 20 & - & 39 & 0.4 & 3.69 \\
\hline C. citrinellus & $\mathrm{R}$ & 1 & - & - & 1 & - & 3 & 2 & - & 30 & 37 & 0.4 & 1.97 \\
\hline C. baronnessa & $\mathrm{R}$ & - & - & - & - & -- & - & - & 1 & 34 & 35 & 0.4 & 0.35 \\
\hline C. vagabundus & $\mathrm{R}$ & 22 & - & 2 & - & - & 1 & 2 & - & - & 27 & 0.3 & 1.83 \\
\hline C. pelewensis & $\mathrm{R}$ & - & - & - & - & - & - & - & - & 20 & 20 & 0.2 & 0 \\
\hline C. lunula & $\mathrm{R}$ & 10 & - & - & 1 & 1 & - & 7 & - & - & 19 & 0.2 & 2.76 \\
\hline C. bennetii & $\mathrm{R}$ & - & 1 & - & - & 4 & - & 3 & 4 & 3 & 15 & 0.2 & 4.16 \\
\hline C. ornatissimus & $\mathrm{R}$ & - & - & - & - & - & - & - & - & 15 & 15 & 0.2 & 0 \\
\hline F. flavissimus & $\mathrm{R}$ & - & - & - & - & - & - & - & - & 15 & 15 & 0.2 & 0 \\
\hline C. unimaculatus & $\mathrm{R}$ & - & - & - & - & - & - & - & - & 11 & 11 & 0.1 & 0 \\
\hline C. kleinii & $\mathrm{R}$ & - & - & - & - & - & - & - & - & 1 & 1 & 0 & 0 \\
\hline $\begin{array}{l}\text { Total per locality } \\
\% \text { of total }\end{array}$ & & $\begin{array}{l}918 \\
9.8\end{array}$ & $\begin{array}{l}1033 \\
11.0\end{array}$ & $\begin{array}{l}984 \\
10.5\end{array}$ & $\begin{array}{l}750 \\
8.0\end{array}$ & $\begin{array}{r}1104 \\
11.8\end{array}$ & $\begin{array}{l}595 \\
6.4\end{array}$ & $\begin{array}{r}1170 \\
12.5\end{array}$ & $\begin{array}{l}1023 \\
10.9\end{array}$ & $\begin{array}{l}1780 \\
19.0\end{array}$ & 9357 & & \\
\hline Spp. per locality & & 13 & 14 & 12 & 13 & 15 & 10 & 16 & 14 & 20 & 23 & & \\
\hline$\%$ of total & & 56.5 & 60.9 & 52.2 & 56.5 & 65.2 & 43.5 & 69.6 & 60.1 & 87.0 & & & \\
\hline Diversity $\mathrm{H}^{\circ}$ & & 1.87 & 1.83 & 1.34 & 1.72 & 2.11 & 1.64 & 2.06 & 1.90 & 1.39 & & & \\
\hline
\end{tabular}

(Table $4 \mathrm{~b}$ ), with a maximum of 49.8 fish per $150 \mathrm{~m}^{2}$ recorded in April 1987. Alternatively, the North Reef Walls generally supported the lowest density whilst the remaining lagoonal localities showed considerable variation in their rankings amongst the different occasions. This was the cause of the significant interaction from the analysis of variance (Table $4 \mathrm{~b}$ ).

The 23 species were assigned to 3 categories according to their overall abundances (Table 3): (1) 3 'abundant' species in total accounted for $65.5 \%$ of all individuals, consisting of Chaetodon rainfordi $(43 \%$ of the total), C. plebius $(11.6 \%)$ and Chelmon rostratus $(10.9 \%)$; (2) 5 'common' species each contributed 3 to $8 \%$ of the total and together accounted for $29.4 \%$ of the overall total with Chaetodon flavirostris, C. trifasciatus, C. melannotus, C. auriga and C. lineolatus; (3) 15 'rare' species (listed in Table 3 ) accounted for the remaining $5.1 \%$ of counts, each contributing from 0.01 to $0.9 \%$ of the total. These species all belonged to the genus Chaetodon except Forcipiger flavissimus.
The 8 abundant and common species were recorded in all 9 localities and each demonstrated relatively broad habitat width $\left(\mathrm{AH}^{\prime}\right)$ (Table 3 ). They did, however, demonstrate species-specific variation in abundances amongst localities and occasions. Results for each of these species are discussed in more detail below.

The rare species comprised 3 groups on the basis of their habitat width $\left(\mathrm{AH}^{\prime}\right)$ (Table 3). Chaetodon speculum, $C$. aureofasciatus and $C$. bennetti, despite having relatively low abundances were widely distributed, demonstrating habitat widths in excess of 4.0 . The second group, including $C$. trifascialis, C. ulietensis, C. ephippium, C. citrinellus, C. vagabundus and $C$. lunula, each with a habitat width between 1.4 and 3.7. occurred in numerous localities but were clearly more abundant in 1 or 2 localities. The third group with $C$. baronnessa, $C$. pelewensis and the 4 rarest species, all had habitat widths either equal to or close to zero as they were essentially observed only on the reef slope. 
Table 4. Summary of results for (a) total number of species of chaetodonts per $150 \mathrm{~mm}^{2}$; (b) total number of individuals per $150 \mathrm{~m}^{2}$ at the 8 localities over the 9 sampling occasions Results from the analyses of variance are: $p<0.05$; $\cdots p<0.01$; ns: not significant. Results of comparisons amongst means by SNK tests are indicated by underlining; means sharing the same line do not differ significantly

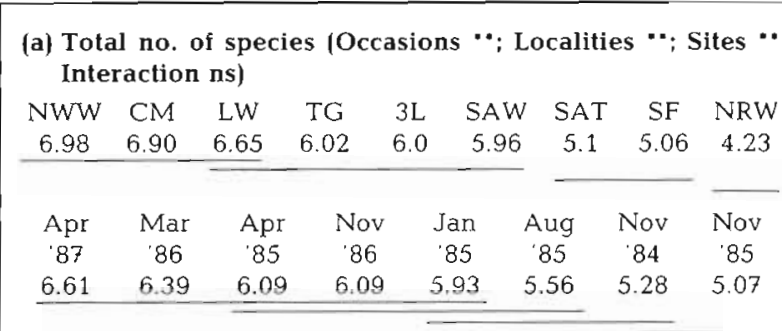

(b) Total no. of individuals (Occasions " "; Localities ' "; Sites ns; Interaction ")

November 1984

LW NWW CM SF 3L SAT TG SAW NRW

$\underline{25.8 \quad 22.3}=$\begin{tabular}{llllllll}
\hline & 15.2 & 14.0 & 13.3 & 12.8 & 12.2 & 12.0 & 5.3
\end{tabular}

January 1985

LW NWW SF CM SAT TG SAW 3L NRW

$\begin{array}{lllllllll}37.0 & 22.5 & 22.8 & 19.0 & 17.7 & 16.2 & 15.3 & 14.7 & 8.0\end{array}$

April 1985

LW NWW TG 3L SAT CM SAW SF NRW

$\begin{array}{lllllllll}41.0 & 32.3 & 30.0 & 27.5 & 26.2 & 24.5 & 22.8 & 13.0 & 11.3\end{array}$

August 1985

LW 3L SAW NWW CM SAT TG SF NRW

$\begin{array}{lllllllll}37.3 & 30.8 & 18.2 & 17.8 & 17.2 & 14.7 & 14.5 & 12.7 & 8.7\end{array}$

November 1985

LW SAT 3L TG NWW SAW SF CM NRW

$\begin{array}{lllllllll}31.7 & 18.2 & 16.2 & 14.0 & 13.0 & 13.2 & 11.7 & 11.5 & 9.7\end{array}$

March 1986

LW NWW SAT SAW CM 3L TG SF NRW

$\begin{array}{lllllllll}37.5 & 34.2 & 29.8 & 30.0 & 28.2 & 19.7 & 19.5 & 18.5 & 14.3\end{array}$

November 1987

LW CM SAW NWW NRW 3L SAT TG SF

$\begin{array}{lllllllll}37.8 & 33.5 & 25.3 & 25.0 & 23.8 & 20.0 & 16.3 & 16.0 & 13.8\end{array}$

April 1987

LW SAW SAT TG CM 3L NWW NRW SF

$\begin{array}{lllllllll}49.8 & 33.5 & 3.0 & 30.3 & 29.8 & 28.5 & 27.5 & 18.2 & 18.5\end{array}$

\section{Abundant species}

Chaetodon rainfordi was the most abundant species. It occurred in every locality on every occasion, and had the highest observed density at any locality on any occasion of 36.8 fish per $150 \mathrm{~m}^{2}$ There was no significant interaction between occasions and localities (Table 5a), and so consistent differences in density
Table 5. Chaetodon rainfordi. Summary of results at the 9 localities over the 8 sampling occasions. Data presented are: (a) density as mean no. per $150 \mathrm{~m}^{2}$, (b) size class ratio (no. in 41-80 mm SL class/total). Results from analyses of variance are indicated as: $\cdot p<0.05 ; \cdots p<0.01$; ns: not significant. Results from SNK tests are indicated by underlining; means sharing the same line do not differ significantly

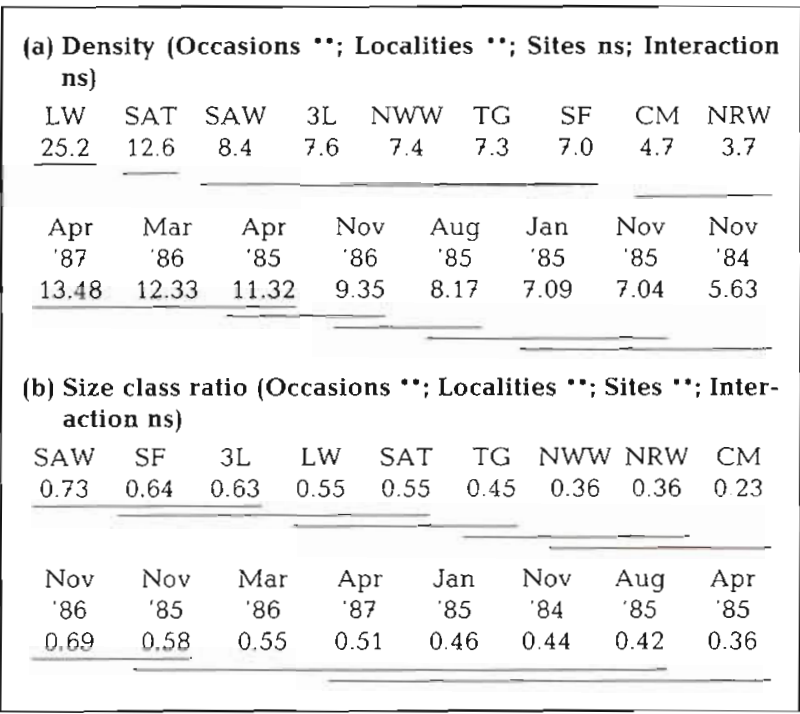

were maintained amongst the 9 localities for the 30 mo period. Leeward Slope and Shark Alley Top supported significantly higher abundances than 5 lagoonal localities that were located close to the outside edge of the reef. These in turn had significantly higher abundances than the 2 localities located closer to the centre of the lagoon, i.e. Central Maze and North Reef Walls (Table 5a). There was a significant positive relationship between fish abundance and total cover of live coral $\left(\mathrm{r}^{2}=0.14, \mathrm{p}<0.05, \mathrm{df}=52\right)$, which possibly accounted for a small proportion of the spatial differences in fish densities. Sampling done in the 3 autumns generally produced significantly higher estimates of density than those from other times of the year (Table 5a) suggesting a possible seasonal influence on observed population sizes.

The populations in the 9 localities demonstrated different characteristics in their size frequency distributions (Fig. 3). This is indicated by the analysis of variance and SNK tests on the proportion of the total comprised by fish in the intermediate size class (41 to $80 \mathrm{~mm} \mathrm{SL}$ ) (Table 5b). In the localities with intermediate-sized populations such as Shark Alley Wall, the dominant size class was 41-80 mm SL. Where populations were most dense (Leeward Slope, Shark Alley Top), the populations consisted of intermediate numbers of this size class and a greater proportion of juveniles ( 0 to $40 \mathrm{~mm} \mathrm{SL}$ ), suggesting that these localities received the highest recruitment rates (Fig. 3, Table 5b). Conversely, at localities where the populations 

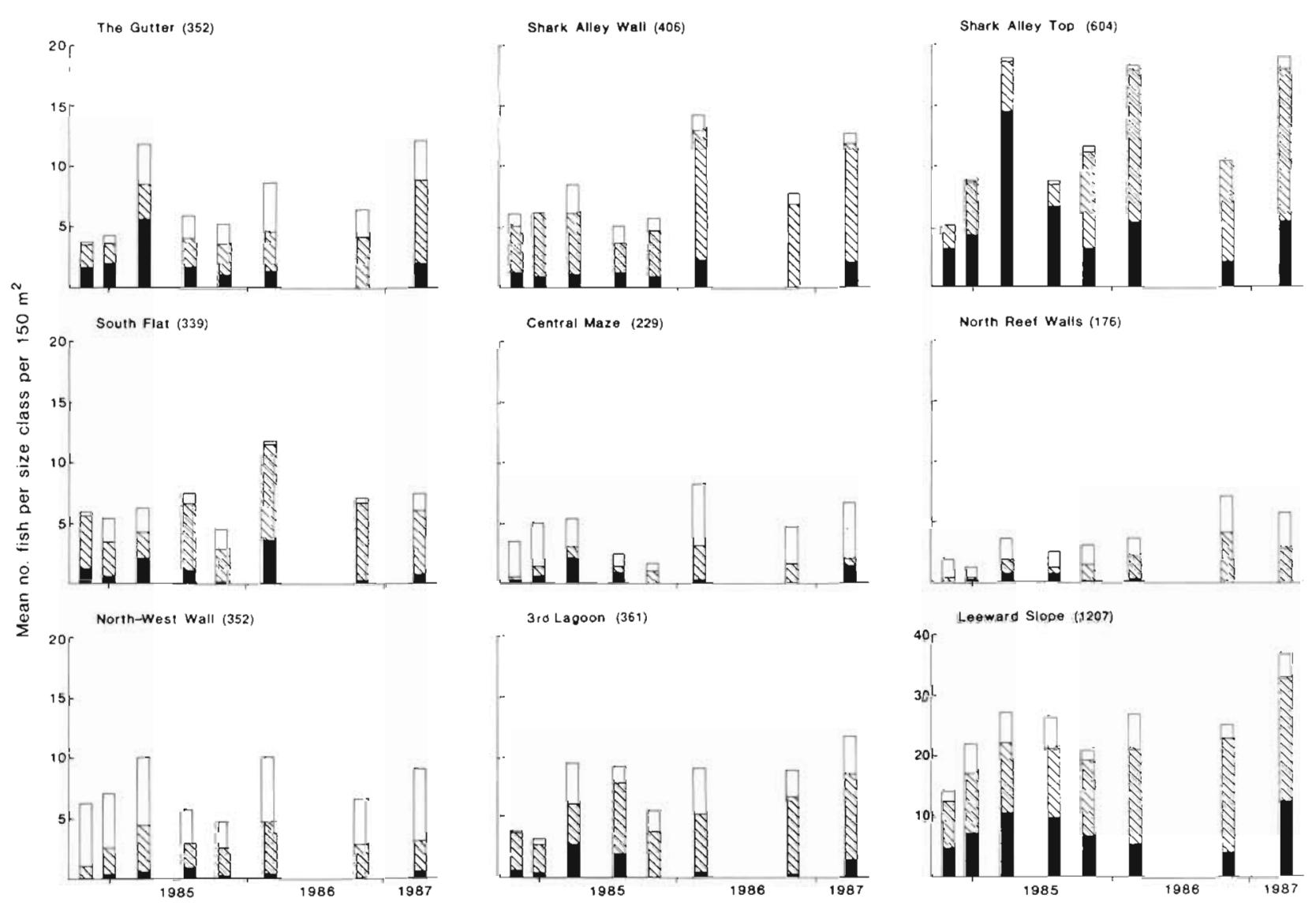

Fig. 3. Chaetodon rainfordi. Mean abundances and size structures of populations at 9 localities on each of the 8 sampling occasions. Total numbers of fish represented in each figure is presented in brackets. Black part of bars: 0-40 mm SL; diagonally shaded part: $41-80 \mathrm{~mm}$ SL; white part $>80 \mathrm{~mm} \mathrm{SL}$. (Note the different Y-axis scale for the Leeward Slope)

were the most sparse (Central Maze, North Reef Walls) the populations had a higher proportion of large adults (>80 mm SL) (Fig. 3, Table 5b).

Chaetodon plebius was the second most abundant species of chaetodont at One Tree Reef, and demonstrated considerable variation in densities amongst occasions, localities and sites (Table 6a). However, the lack of a significant interaction suggests that differences amongst localities were consistent through time. SNK tests did not show considerable separation amongst locality means although there was a trend towards slightly higher densities in the Gutter and towards lower densities at South Flat and North Reef Walls (Table 6a). This pattern of distribution is unlikely to have been related to the distribution of live coral as there was no suggestion of a positive relationship here $\left(r^{2}=0.02, p>0.05, d f=52\right)$. There was a general trend towards slowly increasing population sizes over the course of the study (Table 6a).

The different localities maintained consistent differ-
Table 6. Chaetodon plebius. Summary of results at the 9 localities over the 8 sampling occasions. Format and abbreviations as Table 5

\begin{tabular}{|c|c|c|c|c|c|c|c|c|}
\hline \multicolumn{9}{|c|}{$\begin{array}{l}\text { (a) Density (Occasions } \cdots \text {; Localities } \cdots \text {; Sites } \cdots \text {; Interaction } \\
\text { ns) }\end{array}$} \\
\hline TG & $3 \mathrm{~L}$ & $\mathrm{CM}$ & SAT & NWW & SAW & $\mathrm{LW}$ & SF & NRW \\
\hline 3.52 & 3.29 & 3.23 & 3.02 & 2.60 & 2.52 & 2.42 & 1.40 & 1.04 \\
\hline Apr & Nov & $\mathrm{Ma}$ & & ug & Apr & Jan & Nov & Nov \\
\hline 87 & 86 & 86 & & 85 & ' 85 & 85 & 84 & '85 \\
\hline 3.98 & 3.46 & 2.65 & & 61 & 2.11 & 2.06 & 1.87 & 1.74 \\
\hline
\end{tabular}

(b) Size class ratio (Occasions **; Localities ${ }^{*}$; Sites ${ }^{*}$; Interaction ns)

\begin{tabular}{|c|c|c|c|c|c|c|c|c|}
\hline TG & SAT & LW & SAW & $\mathrm{SF}$ & $3 \mathrm{~L}$ & NWW & CM & NRW \\
\hline 0.72 & 0.67 & & 0.49 & 0.44 & 0.38 & 0.37 & 0.35 & 0.22 \\
\hline Apr & Nov & Mar & $\mathrm{Al}$ & & Nov & Jan & Apr & Nov \\
\hline 87 & 86 & 86 & 8 & & '85 & '85 & '85 & 84 \\
\hline 0.69 & 0.62 & 0.55 & 0. & & 0.36 & 0.35 & 0.34 & 0.33 \\
\hline
\end{tabular}


ences in size-class structure (Table 6b), particularly with regard to the intermediate and largest classes (Fig. 4). For example, at Central Maze and North-West Wall both of these size classes were equally represented, but at 5 localities (The Gutter, Shark Alley Wall, Shark Alley Top, 3rd Lagoon, Leeward Slope) the intermediate size class was always most abundant (Fig. 4). The smallest size class was generally poorly represented, suggesting that recruitment rates were low and varied little through time.

The densities of Chelmon rostratus varied significantly at every level of the sampling hierarchy (Table 7a), suggesting some independence in the densities observed in the different localities. SNK tests were done on interaction means to compare amongst localities on each sampling occasion. Generally, the more protected localities such as North Reef Walls, Shark Alley Wall, Central Maze and North West Wall were ranked higher than the more exposed localities (Leeward Slope, South Flat). There was no relationship between fish abundance and live coral that may have accounted for these spatial patterns $\left(\mathrm{r}^{2}=0.05\right.$, $p>0.05, \mathrm{df}=52$ ). The autumn samples produced the 3 highest mean densities, implying a seasonal influence on observed densities (Table $7 a$ ).

At the 4 localities where the populations were most dense, the fish were primarily between 61 and $100 \mathrm{~mm}$ SL, although at North Reef Walls there was a relatively higher proportion of fish that were $>100 \mathrm{~mm} \mathrm{SL}$ (Fig. 5). The proportion of the populations comprised by fish 81 to $100 \mathrm{~mm}$ SL varied consistently amongst localities being significantly higher at the four localities that generally had the highest densities, than the remaining 5 localities (Table 7 b). The 0 to $60 \mathrm{~mm} \mathrm{SL}$ size class was generally poorly represented except for 2 peaks in The Gutter in April 1985 and April 1987, likely to be related to settlement from the plankton. The first of these peaks did not lead to a subsequent increase in the number of juveniles or adults at this locality (Fig. 5).

\section{Common species}

Chaetodon flavirostris ranged in density from 0.33 to 10.0 fish per $150 \mathrm{~m}^{2}$ on any one occasion. This maximum was unusual and was caused by a school of 54

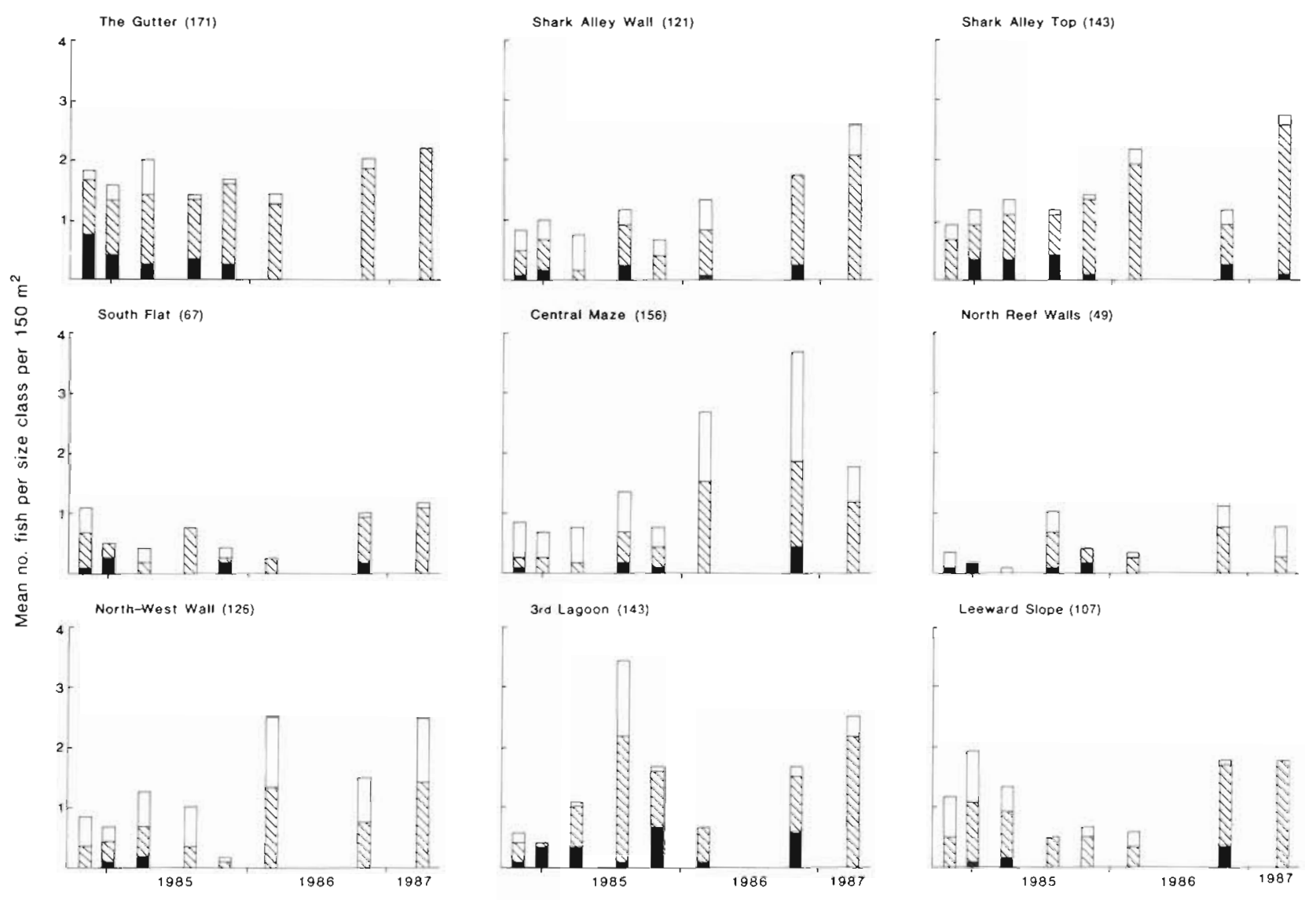

Fig. 4. Chaetodon plebius. Mean abundances and size structures of populations at 9 localities on each of the 8 sampling occasions. Total numbers of fish represented in each figure is presented in brackets. Black part of bars: 0-40 mm SL; diagonally shaded part: $41-80 \mathrm{~mm} \mathrm{SL}$; white part: > $80 \mathrm{~mm} \mathrm{SL}$ 
Table 7. Chelmon rostratus. Summary of results at the 9 localities over the 8 sampling occasions. Data presented are: (a) mean no. per $150 \mathrm{~m}^{2}$ for each locality on the different sampling occasions; (b) size class ratio (no. in $81-100 \mathrm{~mm} \mathrm{SL}$ class/total). Results from analyses of variance are indicated as: $\cdot p<0.05 ; \cdots p<0.01 ;$ ns: not significant. Results from SNK tests are indicated by underlining; means sharing the same line do not differ significantly

\begin{tabular}{|c|c|c|c|c|c|c|c|c|}
\hline \multicolumn{9}{|c|}{$\begin{array}{l}\text { (a) Density (Occasions }{ }^{\prime} \text {; Localities }{ }^{\prime} \cdot \text {; Sites } \boldsymbol{*}^{\prime} \text {; Interaction }{ }^{*} \text { ) } \\
\text { November } 1984\end{array}$} \\
\hline \multicolumn{2}{|c|}{ CM NWTW SAW } & SAW & \multirow{2}{*}{$\begin{array}{c}\text { NRW } \\
1.7\end{array}$} & \multirow{2}{*}{$\begin{array}{l}\text { TG } \\
1.3\end{array}$} & \multirow{2}{*}{$\begin{array}{l}\text { SF } \\
1.0\end{array}$} & \multirow{2}{*}{$\begin{array}{c}\text { SAT } \\
0.8\end{array}$} & \multirow{2}{*}{$\begin{array}{l}\mathrm{LW} \\
0.7\end{array}$} & \multirow{2}{*}{$\begin{array}{l}3 \mathrm{~L} \\
0.3\end{array}$} \\
\hline 2.8 & 2.3 & 2.3 & & & & & & \\
\hline \multicolumn{9}{|c|}{ January 1985} \\
\hline NRW & $\mathrm{CM}$ & SAW & NWW & SAT & $\mathrm{TG}$ & SF & $3 \mathrm{~L}$ & LW \\
\hline 3.8 & 3.7 & 3.3 & 2.5 & 2.0 & 1.3 & 1.3 & 1.2 & 1.2 \\
\hline \multicolumn{9}{|c|}{ April 1985} \\
\hline $\mathrm{CM}$ & NRW & TG & SAW & NWW & SAT & $3 \mathrm{~L}$ & $\mathrm{SF}$ & LW \\
\hline 5.5 & 5.0 & 4.7 & 4.3 & 3.7 & 1.7 & 1.0 & 0.8 & 0 \\
\hline \multicolumn{9}{|c|}{ August 1985} \\
\hline SAW & $\mathrm{CM}$ & NRW & $3 \mathrm{~L}$ & NWW & SAT & TG & LW & $\mathrm{SF}$ \\
\hline 4.5 & 3.3 & 2.5 & 1.8 & 1.5 & 1.2 & 0.8 & 0.3 & 0.2 \\
\hline \multicolumn{9}{|c|}{ November 1985} \\
\hline NRW & $\mathrm{CM}$ & SAW & SAT & TG & NWW & $V \quad \mathrm{SF}$ & $3 \mathrm{~L}$ & LW \\
\hline 3.7 & 2.8 & 2.5 & 1.2 & 1.2 & 1.2 & 0.3 & 0.3 & 0.2 \\
\hline \multicolumn{9}{|c|}{ March 1986} \\
\hline NRW & NWW & SAW & $\mathrm{CM}$ & SAT & TG & $3 \mathrm{~L}$ & SF & LW \\
\hline 6.0 & 5.5 & 5.2 & 4.8 & 2.7 & 2.2 & 1.2 & 1.0 & 0.5 \\
\hline \multicolumn{9}{|c|}{ November 1986} \\
\hline NRW & SAW & $\mathrm{CM}$ & NWW & $3 \mathrm{~L}$ & $\mathrm{SF}$ & SAT & TG & LW \\
\hline 7.3 & 5.3 & 2.5 & 2.3 & 1.3 & 1.2 & 0.8 & 0.7 & 0.2 \\
\hline \multicolumn{9}{|c|}{ April 1987} \\
\hline SAW & NRW & $\mathrm{CM}$ & TG & NWW & SAT & $3 \mathrm{~L}$ & LW & SF \\
\hline 6.3 & 5.0 & 4.7 & 4.3 & 3.7 & 2.7 & 2.3 & 0.5 & 0.5 \\
\hline \multicolumn{9}{|c|}{$\begin{array}{l}\text { (b) Size class ratio (Occasions }{ }^{*} \text {; Localities } \cdots \text {; Sites ns; Inter- } \\
\text { action ns) }\end{array}$} \\
\hline SAW & NRW & $\mathrm{CM}$ & NWW & SAT & TG & $3 \mathrm{~L}$ & $\mathrm{SF}$ & LW \\
\hline 0.53 & 0.51 & 0.50 & 0.43 & 0.26 & 0.21 & 0.17 & 0.16 & 0.13 \\
\hline Nov & Nov & Jan & $A_{F}$ & & ug & Apr & Nov & Mar \\
\hline '86 & '84 & '85 & 8 & 5 & 85 & 87 & 85 & '86 \\
\hline 0.49 & 0.42 & 0.34 & 0.3 & & 29 & 0.28 & 0.20 & 0.17 \\
\hline
\end{tabular}

fish that swam across one transect path. This count caused intractably heterogeneous variances, making the significant result for localities impossible to interpret (thus SNK tests were not done) (Table 8a). NorthWest Wall and South Flat supported marginally higher densities than the remaining localities, whilst Shark Alley Top consistently had the lowest. There was no relationship between fish abundance and coral cover $\left(\mathrm{r}^{2}=0.006, \mathrm{p}>0.05, \mathrm{df}=52\right)$ to account for any spatial pattern. All the remaining results from the analysis of variance can be successfully interpreted, despite the heterogeneous variances, as they were not significant. Therefore, abundances showed little variation through time (Table 8a).

For Chaetodon trifasciatus there was a large difference between localities, with the 2 that supported the most live coral ( $3 \mathrm{~L}$ and LW), supporting the highest densities (Table $8 \mathrm{~b}$ ). This led to a significant relationship between fish and coral abundance $\left(\mathrm{r}^{2}=0.37, \mathrm{p}<\right.$ 0.001 , df $=52$ ). Fish abundances showed no significant variation through time (Table $8 \mathrm{~b}$ ).

Chaetodon melannotus ranged from 0 to $8.8 \mathrm{fish}$ per $150 \mathrm{~m}^{2}$ (Table 9). Three localities (Shark Alley Wall, Central Maze, North-West Wall) had more variable densities over time whilst the remaining six always supported low densities (Table 9). There was no relationship with coral cover $\left(\mathrm{r}^{2}=0.04, \mathrm{p}>0.05\right.$, $\left.\mathrm{df}=52\right)$.

Chaetodon auriga consistently had low densities with a maximum mean in any locality of 3.8 fish per $150 \mathrm{~m}^{2}$. Several widely dispersed lagoonal localities had significantly higher abundances than both Leeward Slope and 3rd Lagoon (Table $8 \mathrm{c}$ ), which led to a significant negative relationship with live coral cover $\left(\mathrm{r}^{2}=0.17, \mathrm{p}<0.05, \mathrm{df}=52\right)$. Although there was no significant variation in density with time there was a slight trend towards recording higher densities during the warmer months (Table 8c).

For Chaetodon lineolatus, South Flat, North-West Wall and Central Maze supported the highest densities (Table 8d) but there was no relationship with coral cover that could account for these differences $\left(\mathrm{r}^{2}=\right.$ $0.0004, \mathrm{p}>0.05, \mathrm{df}=64)$. There was a slight trend towards increasing population size over the last few samples (Table 8d).

\section{DISCUSSION}

In this study, the characteristics of the populations and the assemblages comprised by 23 species of chaetodonts were monitored at 9 widely dispersed localities on one coral reef. The habitats presented by these localities and their dispersion covered a broad range of those available on the reef, so that the recorded characteristics of the fishes are probably typical. Between late 1984 and early 1987, these chaetodonts showed considerable variation amongst the localities, albeit with some temporal variability that led to minor rearrangements of the spatial pattern. Some general patterns emerged from this variability. These are summarised in Table 10, along with information on the diets of the more numerous species, and are discussed below. 

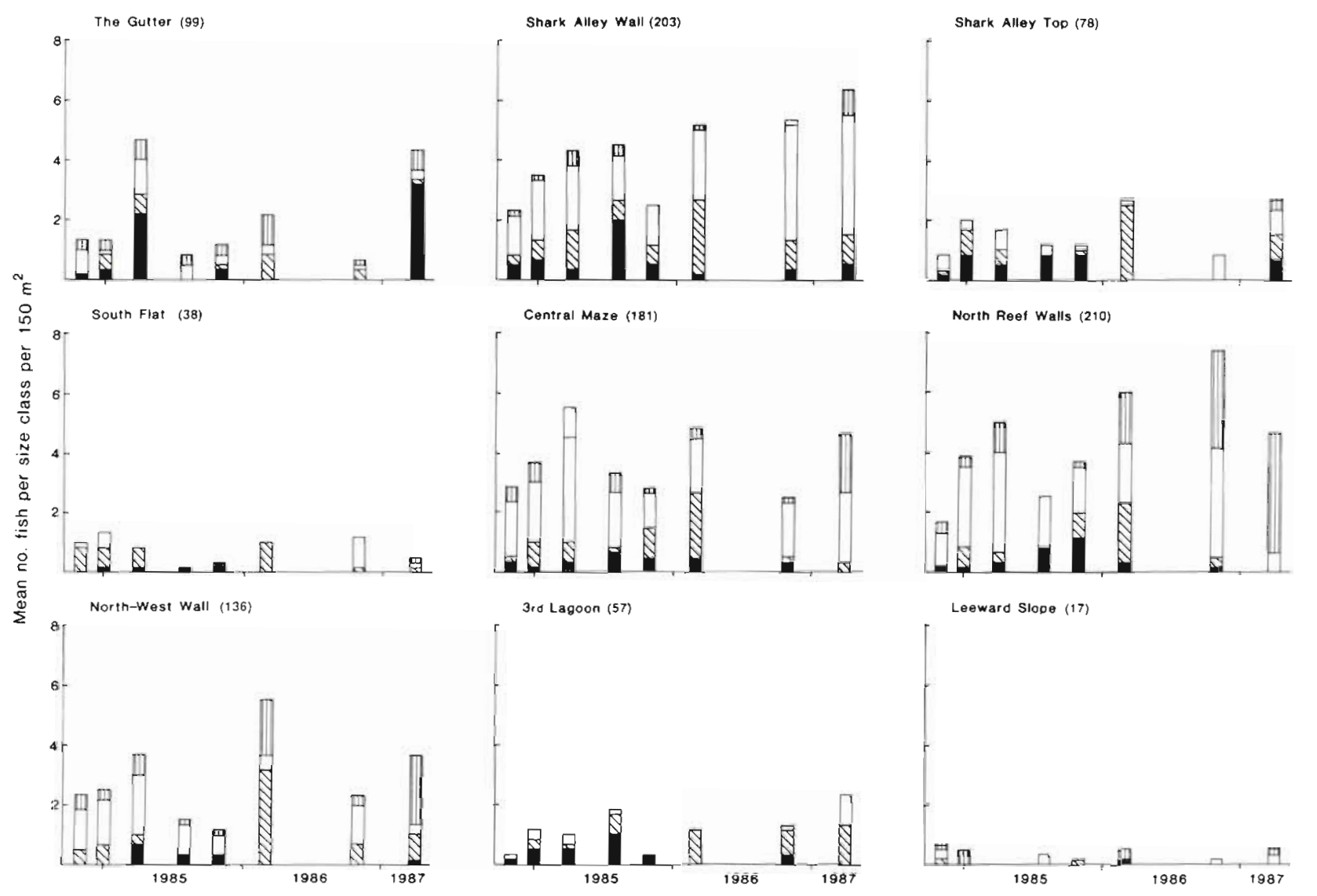

Fig. 5. Chelmon rostratus. Mean abundances and size structures of populations at 9 localities on each of the 8 sampling occasions. Total numbers of fish represented in each figure is presented in brackets. Black part of bars: 0-60 mm SL; diagonally shaded part: $61-80 \mathrm{~mm}$ SL; white part: $81-100 \mathrm{~mm} \mathrm{SL}$ vertically shaded part: $>100 \mathrm{~mm} \mathrm{SL}$

\section{Spatial patterns}

The 8 most numerous species were ubiquitous across the 9 localities, which included 3 different reef zones. Such species, therefore, had sufficiently general habitat requirements to enable survival in a wide range of habitats. Similarly, 3 rare species also were widely dispersed and may have been ubiquitous had they been more abundant. Alternatively, the majority of the rare species had discontinuous distributions. The presence/absence of these rare species helped to determine the assemblage structure. For example, the highest number of species was obtained on the Leeward Slope which supported 12 of the 15 rare species, whilst the lagoonal localities supported from 2 to 8 rare species. The limited distributions of these rare species, relative to the more abundant ones, were either a manifestation of their rareness or that they had more specific habitat requirements.

Since between 10 and 20 species occupied the same localities, there was considerable overlap in the use of space at each locality by confamilial species. As most species of chaetodonts wander over larger areas than the area covered within the dimensions of transects used here (Reese 1975, Sutton 1985, Fowler 1988), it is likely that many species encountered each other on a regular basis, suggesting no obvious finer-scale, within-locality partitioning of space. Such broad overlap in the use of space appears typical for some assemblages of chaetodonts having been previously described for the Bahamas (Clarke 1977), French Polynesia (Bouchon-Navaro 1981, 1986) and the Red Sea (Bouchon-Navaro 1980, 1986, Bouchon-Navaro \& Bouchon 1989). As such, the chaetodonts contrast with other families of reef fish in which confamilial species demonstrate more pronounced spatial segregation both amongst and within habitats. Pomacentrids from the Caribbean and GBR (Clarke 1977, Robertson \& Lassig 1980, Waldner \& Robertson 1980), acanthurids from the Indian Ocean (Robertson \& Gaines 1986) and herbivorous grazing fishes from the central GBR (Russ $1984 \mathrm{a}$, b) all demonstrated considerable habitat segregation amongst related species or amongst those that utilize similar resources. Furthermore, within-habitat segre- 
Table 8 . Summary of results for the 4 common species for which there was no significant interaction. Format and abbreviations for each species as Table 5

(a) Chaetodon flavirostris (Occasions ns; Localities $\cdots$; Sites
ns; Interaction ns)
$\begin{array}{cccccccccc}\text { NWW } & \text { SF } & \text { CM } & \text { NRW } & \text { TG } & \text { SAW } & 3 \mathrm{~L} & \text { LW } & \text { SAT } \\ 3.08 & 2.77 & 1.92 & 1.83 & 1.81 & 1.60 & 1.58 & 1.02 & 0.5 \\ \text { Jan } & \text { Apr } & \text { Apr } & \text { Nov } & \text { Mar } & \text { Aug } & \text { Nov } & \text { Nov } \\ 85 & 85 & 87 & 86 & 86 & 85 & 84 & 85 \\ 2.54 & 2.37 & 1.82 & 1.67 & 1.67 & 1.56 & 1.41 & 1.31\end{array}$

(b) Chaetodon trifasciatus (Occasions ns; Localities '*; Sites *; Interaction ns)

$3 \mathrm{~L}$ LW NWW CM SAW TG SAT SF NRW $\begin{array}{lllllllll}4.83 & 3.06 & 2.19 & 1.63 & 1.31 & 0.29 & 0.29 & 0.19 & 0.08\end{array}$

Apr Apr Nov Nov Mar Jan Aug Nov

\begin{tabular}{llllllll}
\hline 85 & 87 & $' 84$ & 186 & $' 86$ & 185 & $' 85$ & 185
\end{tabular}

\begin{tabular}{llllllll}
1.96 & 1.76 & 1.59 & 1.56 & 1.52 & 1.44 & 1.44 & 1.17 \\
\hline
\end{tabular}

(c) Chaetodon auriga (Occasions ns; Localities ' "; Sites "; Interaction ns)

TG NWW CM SAT SAW SF NRW $3 \mathrm{~L}$ LW $\begin{array}{lllllllll}1.71 & 1.48 & 1.19 & 1.10 & 0.81 & 0.67 & 0.60 & 0.15 & 0.04\end{array}$

Apr Mar Jan Apr Nov Aug Nov Nov

$\begin{array}{llllllll}.87 & 86 & 185 & 185 & .86 & 185 & 184 & ' 85\end{array}$

$\begin{array}{llllllll}1.09 & 1.04 & 1.0 & 0.93 & 0.79 & 0.70 & 0.69 & 0.65\end{array}$

(d) Chaetodon Iineolatus (Occasions "; Localities *'; Sites ns, Interaction ns\}

SF NWW CM TG 3L SAW NRW SAT LW

$\begin{array}{lllllllll}1.13 & 1.13 & 1.10 & 0.65 & 0.63 & 0.35 & 0.23 & 0.21 & 0.08\end{array}$

\begin{tabular}{lccccccc}
\hline & & & & & & \\
\cline { 3 - 6 } Apr & Nov & Apr & Mar & Aug & Jan & Nov & Nov \\
.87 & .86 & 85 & .86 & 85 & 185 & 84 & '85 \\
1.35 & 1.27 & 1.26 & 1.24 & 1.19 & 1.18 & 1.15 & 1.14 \\
\hline
\end{tabular}

Table 9. Chaetodon melannotus. Summary of results at the 9 localities over the 8 sampling occasions. Format and abbreviations as Table 7

\begin{tabular}{|c|c|c|c|c|c|c|c|c|}
\hline \multicolumn{9}{|c|}{$\begin{array}{l}\text { Density (Occasions }{ }^{\prime} \text {; Localities } \cdots \text {; Sites }{ }^{\prime} \text {; Interaction ") } \\
\text { November } 1984\end{array}$} \\
\hline $\mathrm{CM}$ & NWW & LW & $\mathrm{SF}$ & SAT & SAW & TG & $3 \mathrm{~L}$ & NRW \\
\hline 4.5 & 2.3 & 1.3 & 1.3 & 0.7 & 0.5 & 0.3 & 0.2 & 0 \\
\hline \multicolumn{9}{|c|}{ January 1985} \\
\hline $\mathrm{CM}$ & NWW & SAT & $\mathrm{SF}$ & LW & SAW & TG & $3 \mathrm{~L}$ & NRW \\
\hline 4.3 & 2.7 & 1.7 & 1.5 & 0.8 & 0.8 & 0.5 & 0.3 & 0.2 \\
\hline \multicolumn{9}{|c|}{ April 1985} \\
\hline NWW & $\mathrm{CM}$ & SAW & LW & SAT & TG & $3 \mathrm{~L}$ & $\mathrm{SF}$ & NRW \\
\hline 3.7 & 2.5 & 2.5 & 1.5 & 1.2 & 1.0 & 0.7 & 0.3 & 0 \\
\hline \multicolumn{9}{|c|}{ August 1985} \\
\hline NWW & $\mathrm{CM}$ & SAW & SAT & $3 \mathrm{~L}$ & $\mathrm{LW}$ & $\mathrm{SF}$ & TG & NRW \\
\hline 3.2 & 2.8 & 1.2 & 0.8 & 0.8 & 0.8 & 0.5 & 0.3 & 0.2 \\
\hline \multicolumn{9}{|c|}{ November 1985} \\
\hline $\mathrm{CM}$ & SAW & SAT & $\mathrm{SF}$ & NWW & $3 \mathrm{~L}$ & NRW & $\mathrm{LW}$ & TG \\
\hline 2.2 & 1.0 & 1.0 & 1.0 & 1.0 & 1.0 & 0.7 & 0.7 & 0.5 \\
\hline \multicolumn{9}{|c|}{ March 1986} \\
\hline NWW & SAW & SF & $\mathrm{CM}$ & SAT & TG & $3 \mathrm{~L}$ & NRW & LW \\
\hline 4.8 & 2.5 & 2.3 & 1.7 & 1.0 & 0.8 & 0.3 & 0.2 & 0.2 \\
\hline \multicolumn{9}{|c|}{ November 1986} \\
\hline $\mathrm{CM}$ & SAW & NWW & SF & NRW & TG & SAT & LW & $3 \mathrm{~L}$ \\
\hline 8.8 & 3.8 & 3.2 & 1.7 & 1.5 & 1.0 & 0.8 & 0.8 & 0.5 \\
\hline \multicolumn{9}{|c|}{ April 1987} \\
\hline $\mathrm{CM}$ & NWW & $\mathrm{TG}$ & SAW & NRW & $\mathrm{SAT}$ & SF & $3 \mathrm{~L}$ & LW \\
\hline 7.8 & 2.8 & 1.5 & 1.5 & 1.3 & 1.2 & 1.2 & 1.0 & 0.3 \\
\hline
\end{tabular}

Table 10. Chaetodon (C.) spp. and Chelmon (Ch.) rostratus. Summary of results and some characteristics of the 3 abundant and 5 common species. Included are: abundance category: min. and max. density recorded per $150 \mathrm{~m}^{2}$; type of temporal variation; relationship with coral abundance $(\cdot \mathrm{p}<0.05$; ns: not significant); diet; and sources used to determine the diet of each species. References on diet: (1) Reese (1975); (2) Allen (1981); (3) Harmelin-Vivien \& Bouchon-Navaro (1983); (4) Bouchon-Navaro (1986); (5) Fowler (1988)

\begin{tabular}{|c|c|c|c|c|c|c|}
\hline Species & $\begin{array}{l}\text { Abundance } \\
\text { category }\end{array}$ & Density range & $\begin{array}{l}\text { Variation } \\
\text { in time }\end{array}$ & $\begin{array}{l}\text { Relation } \\
\text { with coral }\end{array}$ & Diet & Diet sources \\
\hline C. rainfordi & A & $1.3-36.8$ & Seasonal & - +ve & Obligate corallivore/generalist & (1), (5) \\
\hline C. plebius & A & $0.2-7.3$ & Increasing & ns & Obligate corallivore/generalist & $(1),(5)$ \\
\hline Ch. rostratus & A & $0-7.3$ & Seasonal & ns & Sessile invertebrates & $(2),(5)$ \\
\hline C. flavistrostris & $\mathrm{C}$ & $0.3-10.0$ & - & ns & Omnivore/facultative corallivore & (2) \\
\hline C. trifasciatus & $\mathrm{C}$ & $0-7.5$ & - & $\cdot+\mathrm{ve}$ & Obligate corallivore/generalist & (3), (4) \\
\hline C. melannotus & $\mathrm{C}$ & $0-8.8$ & Increasing & ns & Soft corals & (4) \\
\hline C. auriga & $\mathrm{C}$ & $0-3.8$ & - & - -ve & Omnivore/facultative corallivore & (3), (4) \\
\hline C. lineolatus & $\mathrm{C}$ & $0-2.3$ & Increasing & ns & Omnivore/facultative corallivore & $(1),(2)$ \\
\hline
\end{tabular}

gation has also been described with some territorial species excluding from their territories, fish that utilize similar resources (Low 1971, Belk 1975, Robertson \& Gaines 1986).
The more numerous chaetodonts at One Tree Reef exhibited a less obvious form of habitat discrimination, i.e. not by their presence/absence but by their relative abundances amongst localities. Such relative abundan- 
ces further contributed to the differences in assemblage structure amongst localities. The abundant corallivore Chaetodon rainfordi manifested such a bias in density towards the Leeward Slope as to cause this locality to have by far the most dense assemblage of all localities, but the second lowest diversity $\left(\mathrm{H}^{\prime}\right)$. C. trifasciatus, also an obligate corallivore and also numerous on the leeward slope, occurred in consistently higher densities in 3rd Lagoon. In contrast $C$. auriga, $C$. lineolatus and Chelmon rostratus were all least abundant on the leeward slope, being more numerous in different parts of the lagoon.

Uneven distributions within single reef systems, similar to those described here, are becoming recognised as a general phenomenon (reviewed by Doherty \& Williams 1988, Jones 1988) and have been correlated with physical and biological variables (Jones 1988). As many chaetodonts eat corals, the abundance of coral has been suggested as the likely environmental variable that limits their local population sizes (Bell \& Galzin 1984, Bouchon-Navaro \& Harmelin-Vivien 1985, Hourigan et al. 1988). In this study, the relationships between fish abundance and coral abundance were assessed for the 8 most numerous species, 7 of which are likely to have relied to some extent on corals for food (Table 10). Three significant statistical relationships occurred. Of these one was negative (Chaetodon auriga), and accounted for only a small amount of variation in fish numbers. For 2 of the 3 obligate corallivores, C. rainfordi and C. trifasciatus, the positive relationships accounted for only 14 and $37 \%$ of the total variance in fish numbers, respectively. The remaining obligate corallivore, C. plebius, showed no significant relationship with coral abundance. The diets of some corallivorous chaetodonts are specialised towards particular taxa of corals (reviewed by Hourigan et al. 1988). In such cases, the abundances of fish may be related to the preferred corals rather than the total coral abundance. This is unlikely to have been the case in this study as the 3 obligate corallivores are generalists, which graze on coral taxa in proportion to the abundance of these taxa (Harmelin-Vivien \& Bouchon-Navaro 1983, Bouchon-Navaro 1986, Fowler 1988). Facultative corallivores are also likely to take corals in proportion to their abundance. Therefore, for the 8 most numerous species in this study, it is unlikely that the distribution and abundance of live corals did account for the differences in the densities amongst the different localities.

The amounts of variation accounted for by the relationships with coral abundance described here are similar to those obtained by Bell et al. (1985). These authors considered that such relationships were weak and hypothesised that it was more likely that populations of chaetodonts were limited by recruitment than by the availability of resources. Findley \& Findley (1985) concluded that there was insufficient evidence to support the hypothesis that butterflyfishes from the Caribbean and Pacific live in resource-limited, competitively-structured communities. The present study also supports the conclusions from Bell et al. (1985) and Findley \& Findley (1985) that there is insufficient evidence to relate the numbers of fish to the abundances of corals. Furthermore, the observed spatial differences in the size structures of populations, and therefore the population dynamics of populations separated by small distances, cannot be directly related to the characteristics of the coral fauna. For example, the size structures of both Chaetodon rainfordi and C. plebius appeared better correlated to the recruitment rates of $C$. rainfordi than to coral abundance.

The likelihood that the abundances of chaetodonts at One Tree Reef are not limited directly by the abundances of their food resources does not preclude the significance of the presence of corals. Where large perturbations of reefs have resulted in a severe decline in the abundance of corals, this has resulted in a subsequent crash in the populations of chaetodonts (BouchonNavaro \& Harmelin-Vivien 1985, Williams 1986, Russ \& Alcala 1989). This indicates that the distributions of corals and chaetodonts are correlated as the corals represent a necessary resource, but does not indicate that the level of this resource is the limiting factor for population sizes.

\section{Temporal variability}

There were no dramatic changes in population densities over the $30 \mathrm{mo}$, and the abundant, common and rare species remained as such throughout. For 3 of the 8 numerous species (Chaetodon flavirostris, $C$. trifasciatus, $C$. auriga) there were no significant changes in population densities with time. For 2 species (C. rainfordi, Chelmon rostratus) part of the significant temporal variability was seasonal, with counts in the austral autumn consistently higher than those from other times of the year. For both of these species, this seasonality was at least partly related to settlement from the plankton followed by subsequent depletion of the cohort by growth and mortality. This phenomenon has been described for reef fishes previously by Kingett \& Choat (1981) and Jones (1984). However, in this case recruitment could not account for all the seasonal variation in the observed densities as the numbers of larger fish also varied. One possible further explanation for this is that the behaviour of the fish changed seasonally making them more susceptible to observation at warmer times of the year. Although further work is required to test this, the observation has 
significant implications for the interpretation of patterns of abundance of such species, suggesting that data recorded only at the same time each year can be used to assess population variation through time.

The extent of population change through time in reef fishes is highly species specific (Ebeling et al. 1980, Stephens \& Zerba 1981). Some populations have shown considerable constancy over periods of 3 to $4 \mathrm{yr}$ (Jones 1984, Eckert 1985), whereas others have shown considerable variability, even over several months (Talbot et al. 1978, Sale 1980, Williams 1980, Bohnsack 1983, Sale \& Douglas 1984, Eckert 1985, McCormick 1989). For most species considered in this study the variation through time within localities was less significant than the spatial differences amongst localities, as such differences were maintained over the 30 mo period. This same conclusion was reached by Jones (1988) in his assessment of the relative significance of temporal and spatial variation in population sizes of temperate reef fish, within single reef systems.

It is difficult to consider the 'constancy' or 'stability' of population sizes on the observations of the comparatively small temporal changes documented here. This is in part related to the potential behavioural problem outlined above and that the duration of this study was less than the average life span of the species considered (Fowler 1988). Studies of duration of at least one generation are required to assess temporal change in population size (Connell \& Sousa 1983, Mapstone \& Fowler 1988). Therefore, a circumspect interpretation of the low temporal variability observed here is recommended.

At One Tree Reef, populations of some species of chaetodonts, separated by only small distances, consistently maintained different patterns of distribution, abundance and size structure, albeit within a framework of some temporal variability. Relationships between fish abundance and coral abundance either were not detected or were weak, suggesting that population densities were not determined by the levels of this resource. Considerable evidence has been presented in recent years that sizes of populations of coral reef fishes can be recruitment-determined (reviewed by Doherty \& Williams 1988). Although the data presented here are insufficient to test this hypothesis, there are some supporting features. Recruitment rates of both Chaetodon rainfordi and Chelmon rostratus were variable in both space and time. Furthermore, for the former species, the 2 localities that received the highest recruitment also supported the highest density of fish, and those with low recruitment rates had the lower population sizes.

Generally, the recruitment rates of chaetodonts are low compared with some other reef fishes (Sale et al. 1984, Fowler 1988), which is likely to be related at least in part to the low numbers of pre-settlement chaetodonts that occur in the vicinity of and in waters distant from coral reefs (Leis 1989). Low settlement rates due to the low availability of pre-settlement fish may explain why populations do not reach levels where they approach limits set by resources. However, in order to explain the presence/absence of rare species and the uneven relative abundances of the more numerous species further explanations such as habitat-selection at the time of settlement and post-settlement migration must be implicated. Only documentation of settlement rates and the monitoring of the survival and movement patterns of juveniles and adults can discriminate between such hypotheses. This highlights one further shortfall in our knowledge on the ecology of coral reef fishes, and presents one essential area where research effort must be directed if our understanding in this field is to progress.

Acknowledgements. The comments of M. Cappo P. Doherty, B. Mapstone, S. Thorrold and 3 anonymous referees helped improve earlier drafts of this paper. The study was supported by the University of Sydney and by a grant to Professor P. Sale from the Great Barrier Reef Marine Park Authority, whilst the author was supported by a Commonwealth Postgraduate Research Award. This is a contribution from the One Tree Island Field Station.

\section{LITERATURE CITED}

Allen, G. R. (1981). Butterfly and angelfishes of the world, Vol. 2. John Wiley and Sons, New York

Anderson, G. R. V., Erhlich, A. H., Ehrlich, P. R., Roughgarden, J. D., Russell, B. C., Talbot, F. H. (1981). The community structure of coral reef fishes. Am. Nat. 117: 476-495

Belk, M. S. (1975). Habitat partitioning in two tropical reef fishes Pomacentrus lividus and $P$. albofasciatus. Copeia 1975: 603-607

Bell, J. D., Galzin, R. (1984). Influence of live coral cover on coral-reef fish communities. Mar. Ecol. Prog. Ser. 15: 265-274

Bell, J., Harmelin-Vivien, M., Galzin, R. (1985). Large scale spatial variation in abundance of butterflyfishes (Chaetodontidae) on Polynesian reefs. Proc. 5th Int. Coral Reef Cong., Tahiti 5: 421-426

Bohnsack, J. A. (1983). Species turnover and the order versus chaos controversy concerning reef fish community structure. Coral Reefs 1: 223-228

Bouchon-Navaro, Y. (1980). Quantitative distribution of the Chaetodontidae on fringing reef of the Jordanian Coast (Gulf of Aqaba, Red Sea). Tethys 9: 247-251

Bouchon-Navaro, Y. (1981). Quantitative distribution of the Chaetodontidae on a reef of Moorea Island (French Polynesia). J. exp. mar. Biol. Ecol. 55: 145-157

Bouchon-Navaro, Y. (1986). Partitioning of food and space resources by chaetodontid fishes on coral reefs. J. exp. mar. Biol. Ecol. 103: 21-40

Bouchon-Navaro, Y., Bouchon, C. (1989). Correlations between chaetodontid fishes and coral communities of the Gulf of Aqaba (Red Sea). Environ. Biol. Fish. 25: 47-60

Bouchon-Navaro, Y., Harmelin-Vivien, M. L. (1985). Impact of 
coral degradation on a chaetodontid fish assemblage (Moorea, French Polynesia). Proc. 5th Int. Coral Reef Congress, Tahiti 5: 427-432

Clarke, R. D. (1977). Habitat distribution and species diversity of chaetodontid and pomacentrid fishes near Bimini. Bahamas. Mar. Biol. 40: 277-289

Colwell, R. K. (1983). What's new? Community ecology discovers biology. In: Price, P. W., Slobodchikoff, C. N., Gaud, W. S. (eds.) A new ecology. Novel approaches to interactive systems. John Wiley and Sons, New York, p. 388-396

Connell, J. H. (1978). Diversity in tropical rainforests and coral reefs. Science 199: 1302-1309

Connell, J. H., Sousa, W. P. (1983). On the evidence needed to judge ecological stability or persistence. Am. Nat. 121: 789-824

Doherty, P. J., Williams, D. McB. (1988). The replenishment of coral reef fish populations. Oceanogr. Mar. Biol. A. Rev. 26: $487-551$

Ebeling, A. W., Larson, R. J., Alevizon, W S., Bray, R. N (1980). Annual variability of reef-fish assemblages in kelp forests of Santa Barbara, California. Fish. Bull. U.S. 78: 316-377

Eckert, G. J. (1985). Population studies on labrid fishes on the southern Great Barrier Reef. Ph. D. thesis, University of Sydney

Findley, J. S., Findley, M. T. (1985). A search for pattern in butterflyfish communities. Am. Nat. 126: 800-816

Fowler, A. J. (1987). The development of sampling strategies for population studies of coral reef fishes. A case study. Coral Reefs 6: 49-58

Fowler, A. J. (1988). Aspects of the population ecology of three species of chaetodonts at One Tree Reef, southern Great Barrier Reef. Ph. D. thesis. University of Sydney

Harmelin-Vivien, M. L., Bouchon-Navaro, Y. (1983). Feeding diets and significance of coral feeding among chaetodontid fishes in Moorea (French Polynesia). Coral Reefs 2: $119-127$

Hourigan, T. F., Tricas, T. C., Reese, E. S. (1988). Coral reef fishes as indicators of environmental stress in coral reefs. In: Soule, D. F., Kleppel, G. S. (eds.) Marine organisms as indicators. Springer-Verlag, New York, p. 107-136

Jones, G. P. (1984). Population ecology of the temperate reef fish Pseudolabrus celidotus Bloch and Schneider (Pisces: Labridae). II. Factors influencing adult density. J. exp. mar. Biol. Ecol. 75: 277-303

Jones, G. P. (1988). Ecology of rocky reef fish of north-eastern New Zealand. N. Z. J. mar. Freshwat. Res. 22: 445-462

Kingett, P. D., Choat, J. H. (1981). Analysis of density and distribution patterns in Chrysophrys auratus (Pisces: Sparidae) within a reef environment: an experimental approach. Mar. Ecol. Prog. Ser. 5: 283-290

Leis, J. M. (1989). Larval biology of butterflyfishes (Pisces, Chaetodontidae): what do we really know? Environ. Biol. Fish. 25: 87-100

Low, R. M. (1971). Interspecific territoriality in a pomacentrid fish, Pomacentrus flavicauda Whitley. Ecology 52: $648-654$

Mapstone, B. D., Fowler, A. J. (1988). Recruitment and the structure of assamblages of fish on coral reets. Trends Ecol. Evolut. 3: 72-77

McCormick, M. I. (1989). Spatio-temporal patterns in the abundance and population structure of a large temperate reef fish. Mar. Ecol. Prog. Ser. 53: 215-225

Pielou, E. C. (1974). Population and community ecology: principles and methods. Gordon and Breach Science Publishers, New York
Reese, E. S. (1975). A comparative field study of the social behaviour and related ecology of reef fishes of the family Chaetodontidae. Z. Tierpsychol. 37: 37-61

Reese, E. S. (1981). Predation on corals by fishes of the family Chaetodontidae. Implications for conservation and management of coral reef ecosystems. Bull. mar Sci. 31: 594-604

Robertson, D. R., Lassig, B. (1980). Spatial distribution patterns and co-existence of a group of territorial damselfishes from the Great Barrier Reef. Bull. mar Sci. 30: $187-203$

Robertson, D. R., Gaines, S. D. (1986). Interference competition structures habitat use in a local assemblage of coral reef surgeonfishes. Ecology 67: 1372-1383

Russ, G. (1984a). Distribution and abundance of herbivorous grazing fishes in the central Great Barrier Reef. I. Levels of variability across the entire continental shelf. Mar. Ecol. Prog. Ser. 20: 23-34

Russ, G. (1984b). Distribution and abundance of herbivorous grazing fishes in the central Great Barrier Reef. II. Patterns of zonation of mid-shelf and outer-shelf reefs. Mar. Ecol. Prog. Ser, 20: 35-44

Russ, G., Alcala, A. C. (1989). Effects of intense fishing pressure on an assemblage of coral reef fishes. Mar. Ecol. Prog. Ser. 56: 13-27

Russell, B. C. (1983). Annotated checklist of the coral reef fishes in the Capricom-Bunker Group Great Barrier Reef Australia. Great Barrier Reef Marine Park Authority, Townsville, Australia

Sale, P. F. (1980). The ecology of fishes on coral reefs. Oceanogr. mar. Biol. A. Rev. 18: 367-421

Sale, P. F. (1984). The structure of communities of fish on coral reefs and the merit of a hypothesis testing manipulative approach to ecology. In: Strong, D. R. Jr, Simberloff, D., Abele, L. G., Thistle, A. B. (eds.). Ecological communities: conceptual issues and the evidence. Princeton University Press, Princeton, p. 478-490

Sale, P. F., Doherty, P. J., Eckert, G. J., Douglas, W. A., Ferrell, D. J. (1984). Large scale spatial and temporal variation in recruitment to fish populations on coral reefs. Oecologia (Berl.) 64: 191-198

Sale, P. F., Douglas, W. A. (1984). Temporal variability in the community structure of fish on coral patch reefs and the relation of community structure to reef structure. Ecology 65: $409-422$

Sale, P. F., Jones, G. P., Choat, J. H., Leis, J. M., Thresher, R. E., Williams, D. McB. (1985). Current priorities in ecology of coral reef fishes. Search 16: 270-274

Sokal, R. R., Rohlf, F. J. (1981). Biometry. W. H. Freeman and Co., New York

Stephens, J. S., Zerba, K. E. (1981). Factors affecting fish diversity on a temperate reef. Environ. Biol. Fish. 6: $111-121$

Sutton, M. (1985). Patterns of spacing in a coral reef fish in two habitats on the Great Barrier Reef. Anim. Behav. 33: $1332-1337$

Talbot, F. H., Russell, B. C., Anderson, G. R. V (1978). Coral reef fish communities: unstable, high-diversity systems? Ecol. Monogr. 48: 425-440

Waldner, R. E., Robertson, D. R. (1980). Patterns of habitat partitioning by eight species of territorial Caribbean damselfishes (Pisces: Pomacentridae). Bull. mar Sci. 30 $171-186$

Wiens, J. A. (1984). On understanding a non-equilibrium world: myth and reality in community patterns and processes. In: Strong, D. R. Jr, Simberloff, D., Abele, L. G., Thistle, A. B. (eds). Ecological communities: conceptual 
issues and the evidence. Princeton University Press, Princeton, p. 439-457

Williams, D. McB. (1980). Dynamics of the pomacentrid community on small patch reefs in One Tree lagoon (Great Barrier Reef). Bull. mar. Sci. 30: 159-170

Williams, D. McB. (1986). Temporal variation in the structure of reef slope fish communities (central Great Barrier Reef):

This article was presented by Dr D. Klumpp, Townsville, Australia short term effects of Acanthaster planci infestation. Mar Ecol. Prog. Ser. 28: 157-164

Williams, D. McB., Hatcher, A. I. (1983). Structure of fish communities on outer slopes of inshore, mid-shelf and outer shelf reefs of the Great Barrier Reef. Mar. Ecol. Prog. Ser 10: $239-250$

Manuscript first received: May 18, 1989

Revised version accepted: March 22, 1990 